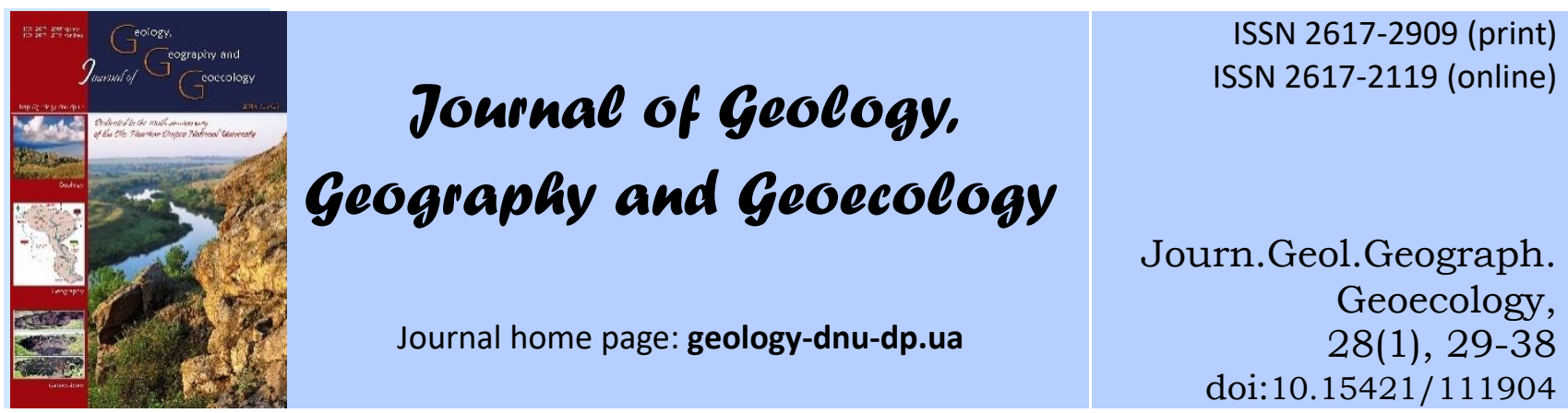

O.B. Chernega, G.O. Gorina, O.M. Romanukha,

G.A. Bohatyryova, K.V. Nikolenko

Journ.Geol.Geograph.Geoecology, 28(1), 29-38

\title{
Comparative analysis of the regional markets of cultural and cognitive tourism development in Ukraine
}

\author{
O.B. Chernega, G.O. Gorina, O.M. Romanukha, G.A. Bohatyryova, K.V. Nikolenko
}

Donetsk national university of economics and trade named after Mykhailo Tugan-Baranovsky, Kryvyi Rih, Ukraine, e-mail: romanukha@donnuet.edu.ua

Received 21.11.2018;

Received in revised form 14.01.2019;

Accepted 28.01.2019

Abstract. The purpose of the article is an implementation of the comparative analyses of development of regional markets of cultural and cognitive tourism in Ukraine. The theoretical and methodological basis of research is the ideas of the theoryof tourism, theory of management, works of the leading native and foreign scholars regarding the development of the touristic services market. To achieve the desired goal, the following research methods were used: the system and complex analyses (for determination of the development tendencies of the regional markets of the cultural and cognitive tourism in Ukraine); calculation-analytical and comparative methods (for determination of the centers of the regional markets of the cultural and cognitivetourism in Ukraine); cartographical method (for visual demonstration of the emphasized touristic regions of the cultural and cognitive tourism in Ukraine). The regionalized territory of Ukraine according to the development of the cultural and cognitivetourism, which is based on the calculation of average data of the quantity of the museums according to the regions, analysis of their visitations and of the volume of the tourist flows permitted to emphasize four formed regions of the cultural and cognitive tourism: Western, including Lviv, Ivano-Frankivsk, Ternopil, Chernivtsi, Zakarpattia, Volyn, Rivne and Khmelnytsk regions; Northern - city of Kyiv and Kyiv, Zhytomyr, Cherkasy, Chernihiv, Vinnytsia, Kirovohrad regions; Eastern - Kharkiv, Sumy, Poltava, Dnipropetrovsk, Zaporizhzhia, Donetsk, Luhansk regions; Southern - Autonomous Republic of Crimea, Kherson, Mykolaiv, Odesa regions. The conducted analyses of the emphasized regions permitted emphasize the modern tendencies of development of the cultural and cognitive tourism market in Ukraine, namely: the availability of substantial disparity of its development according to the regions of Ukraine; refocusing of the touristic flows from the South-Eastern regions to the North-Western as a result of annexation of Crimea and military conflict in the east of Ukraine; the sustained development of the cultural and cognitive tourism of the North region at the expense of the extensivediversification of the available offer and possibility to meet the requirements of all groups of tourists; the highest rates of development of the cultural and cognitive tourism in the West region caused by the attraction of the tourists from the other regions of Ukraine with activation of the natural and historical advantages use.

Keywords: tourism, marketofthecultural and cognitive tourism, museum, tourist flow, tourism industry.

\section{Компаративний аналіз розвитку регіональних ринків культурно-пізнавального туризму в Україні}

\author{
О.Б. Чернега, Г.О. Горіна, О.М. Романуха, Г.А. Богатирьова, К.В. Ніколенко
}

Донецький національний університет економіки та торгівлі імені Михайла Туган-Барановського, м. Кривий Ріг, Україна.е-mail: romanukha@donпиеt.edu.иа

Анотація. Здійснено районування території України за розвитком культурно-пізнавального туризму, яке базується на розрахунку середньостатистичних даних кількості музеїв за регіонами, аналізу їх відвідувань та обсягу туристичних потоків. Це дозволили виділити чотири сформовані регіони культурно-пізнавального туризму: Західний, що включає Львівську, Івано-Франківську, Тернопільську, Чернівецьку, Закарпатську, Волинську, Рівненську і Хмельницьку області; Північний - м. Київ та Київська, Житомирська, Черкаська, Чернігівська, Вінницька, Кіровоградська області; Східний Харківська, Сумська, Полтавська, Дніпропетровська, Запорізька, Донецька, Луганська області; Південний - АР Крим, Херсонська, Миколаївська, Одеська області. Встановлено, що кількість туристів у інших областях України була прямопропорційна їх віддаленості від зазначених центрів. Проведено компаративний аналіз діяльності музеїв за регіонами України, в основі якого було покладено данні з кількості відвідувань музеїв, наявності та якості експозиційного фонду, професійних кафрів, використання сучасних інформаційних технології у музейній справі. Проведений аналіз виокремлених 
регіонів дозволив виділити сучасні тенденції розвитку ринку культурно-пізнавального туризму в Україні, а саме: наявність значної диспропорції його розвитку за регіонами України; переорієнтація туристичних потоків з Південно-Східних регіонів до Північно-Західних як результат анексії Криму та військового конфлікту на Сході України; стійкий розвиток культурнопізнавального туризму Північного регіону за рахунок широкої диверсифікації наявної пропозиції та можливості задовільнити потреби усіх груп туристів; найвищі темпи розвитку культурно-пізнавального туризму у Західному регіоні спричинені залученням туристів з інших регіонів України за допомогою активізації використання природніх та історичних переваг.

Ключові слова: туризм, ринок культурно-пізнавального туризму, музей, туристичні потоки, туристична галузь.

Introduction. A quick development of the society activates the development of new economy directions. A perfect example for this is the tourism. Having activated at the end of the XIX ${ }^{\text {th }}$ century, it obtained the great rate of development in the $\mathrm{XXI}^{\text {st }}$ century. Having turn into the integrated factor of many spheres of human existence, tourism has become one of the pillars of the world economy, aninstrument of removing interethnic confrontation, rising of the level of people's education and etc. Today, the dependence of the level of the country'sdevelopment from the level of development of its tourism industry - is directly proportional. Therewith the world practice certifies that the cultural and historical resources become the main object of tourist attention.

Museums attract more and more visitors, transform the principles of their activities, are moving on to a social and market functioning model. They promote the rise of the social status of regions, determinate development of the tourist infrastructure - of the roads, airports, hotels, public catering system, condition the new jobs formation. The advanced countries of the world have made long ago the museums as a basis of their own tourist development, ensuring for themselves the economic growth in the fields related to tourism and museums. The museum for them became as a symbiosis of culture, education, science and economics. The purpose of the work is to carry out a comparative analysis of the development of regional marketsof the cultural and cognitive tourism in Ukraine.

The role of the cultural and cognitive tourism in the development of the tourism industry of Ukraine was studied both as native as foreign scientists. It is import to note among the general works the work of H.O. Gorina(Gorina, 2015). She draws attention to the conceptual framework of the tourism industry in Ukraine. $\mathrm{H}$. H.Vyshnevskastudies the potential of the cultural and cognitive tourism in preserving of the cultural heritage of Ukraine (Vyshnevska, 2013). The significant is a work of Yu.M. Kliuchko (Kliuchko, 2011). The author studies a role of museums and of excursion work in the formation of cultural tourism.The question of excursion work of museums and the meaning of it in the modern society was studied by V. M. Beketova (Beketova, 1998). The researcher raised in her work the sociocultural aspects for functioningof museums, excursions, their influence on the society and a level of popularity among people. Melko L.F. makes a detailed study regarding generalization and systematization of the research vocabulary of the cultural and cognitive tourism (Melko, 2013).

The different aspects of development of the cultural and cognitive tourism were raised in the works of the foreign scientists. O. Barna, C. Serea specifiedwith the statistical methods:the historical monuments which are preferred by the tourists when they go on holidays, exists or no a correlation between them and the determining factor in choosing of the holiday destinations (Barna, Serea, 2017). Zbuchea A.investigates the motives and activities that tourists are undergoing during their vacations abroad in order to identify the place of culture in this context (Zbuchea, 2012).SmithM. and RobinsonM. are critically examine the dynamic inter-relationships between tourism and culture(s). They areinvited to consider such relationships under theoretical explorations, research-informed analyses, and detailed historical reviews from a variety of disciplinary perspectives.

Material and methods of the research. The theoretical and methodological base of research became the provisions of the theoryof tourism, theory of management, the works of the leading native and foreign scientists regarding development of the touristic services market. To achieve the desired goal, the following research methods were used: the system and complex analyses (for determination of the development tendencies of the regional markets of the cultural and cognitive tourism in Ukraine); calculation-analytical and comparative methods (for determination of the centers of the cultural and cognitive tourism in Ukraine); cartographical method (for visual demonstration of the emphasized touristic regions of the cultural and cognitive tourism in Ukraine).

The accuracy of the received results is provided with the use of the official data of the State Statistics Service of Ukraine. At the same time, for the most reasonable and detailed allocation of the tourist regions of cultural and cognitive tourism in Ukraine could be promoted by 
the availability of sociological surveys regarding the satisfaction of visitors with the quality of museum pieces and excursion services, systematized statistical data regarding implementation of the world experience of implementation of interactive technologies in the state museums, data regarding volumes of the investments attraction in this industry, etc.

Findings and their analysis. The touristic branch of Ukraine is a perspective direction for the development of the national economics. The rich history, cultural heritage, nature - form the unique offers for rest, educational, cultural or even extreme tourism. At the modern stage, Ukraine can offer aninformative list of places and institutions for cultural and cognitive tourism, which will satisfy the needs of any visitor. From the industrial objects and museums in the East of Ukraine to the picturesque landscapes and castles in the West, from the ruins of ancient Greek cities-polises in the South to ancient temples-museums in the North of the country.The thematic and regional location of objects of cultural and cognitive tourism has a certain regularity, which can be reflected on a map of the tourist regionalization of Ukraine. At the moment, there exist several variants of such zoning. M. Malska, V. Khudomake accent on the following recreation zones in Ukraine: Crimean, Western Prychernomorsk zone, Carpathian, Azov, CentralUkrainian, Podolsk (Malska, Khudo, 2007).

Whereas, M. Krachylo identifies 5 tourist regions within 2 zones at the territory of Ukraine: Crimea, Odesa, Azov (compose the Crimea-OdesaAzov region), Dnipro-Dniester, Carpathians.These approaches were very close, except of the zoning of the territories of Western Ukraine. Later, the existing proposals were supplemented by another variant of the country regionalization. O.O. Beidyk proposed a sectoral regionalization, which divided the country into 6 districts: Carpathians; PolissiaPodilsk; Kyiv-Dniprovsk; Donetsk-Dniprovsk; Prychernomorsk; Crimea districts. Their boundaries were passed by region boundaries, uniting all administrative and territorial units of Ukraine (Beidyk, 2010). The author's development of the tourist recreational regionalization according to the method of professor F. Zastavnyi was offered by V. Kosharnyi. He offers to divide the therritory of Ukraine on 10 zones: the Ukrainian Carpathians; VolynPolissia;Podillia; Kyiv Polissia; the Middle Prydniprovia; KaterynoslavskePrydniprovia; SlobidskaUkraina; Donbas; Odesa-Tavriisk region; Crimea (Kosharnyi, 2017). At the same time, many researchers in the analysis of the tourist potential of the regions of Ukraine base themselves upon its administrative-territorial division. Taking this into account, to determine the regions of cultural and cognitive tourism of Ukraine, we will take as a basis of the study namely the administrativeterritorial division of the country.

The methodology for realization of regionalization of the territory of Ukraine in cultural and cognitive tourism is based on the detection principle of the part of museums in the regions and calculation according to the received results of the average data (the percent). As a result of the obtainedresults, it can be separated four centers of cultural and cognitive tourism at the territory of Ukraine: Western; Central; Eastern; Southern. According to the calculations presented in Table 1, the largest percentage of museums according to the regions of Ukraine was in: Kiev; Chernihiv, Cherkasy; Poltava; Kharkiv; Kirovograd Ternopil; Lviv regions; Autonomous Republic of Crimea. At the second place were Ivano-Frankivsk; Vinnytsia; Khmelnytsk; Dnipropetrovsk; Zaporizhzhia regions. All other regions of Ukraine had the average indicator from 0,1 to 3,7 . The availability of the biggest number of museums in Lviv, Kyiv, Kharkiv regions and Autonomous Republic of Crimea is historically contingent. These regions actually represented at different ages the centers of socio-political, economic, foreignpolicy, cultural life of the certain parts of Ukraine. In the periodof reign of the Austrian and Russian empires in Ukraine, Lviv and Kharkiv were as the great administrative centers where the first universities, theaters and museums were opened.They were the capitals of state formations: Lviv - Western-Ukrainian people's republic, Kharkiv- Ukrainian SSR. The significance of Kyiv as the political center of Ukrainian lands is referred tothe moment of KyivskaRusformation. The Autonomous Republic of Crimea was the administrative and political center of Mala Skifiia, Bosporankingdom, of a number of ancient Greek cities-polises, and of the Crimean Khanate.

It should be noted all calculations regarding the Autonomous Republic of Crimea, Donetsk and Luhansk regions were conducted taking into account the loss of control over a part of the territories through the annexation of Crimea and the beginning of a military conflict in the East of Ukraine,which actually blocked the work of their tourist complexes for an indefinite time.These assertions and results of analysis of the regional distribution of the tourists are confirmed in Ukraine. Comparing the percentage of tourists according to the regions of Ukraine, it can be divided into four centers with the biggest number of tourist visits: Western (Lviv, Ivano-Frankivsk regions); North (Kyiv region and city of Kyiv); 
Eastern-Central (Kharkiv, Dnipropetrovsk, Zaporizhzhia regions); Southern (Odessa region).The quantity (percent) of tourists in the other regions of Ukraine was directly proportional to their distance from the mentioned centers. By comparing the obtained data regarding the distribution of the number of museums and tourists according to the regions of Ukraine we obtain a coincidence of indicators. This gives grounds toaffirm the existence of four historically formed regions of the cultural and cognitive tourism in Ukraine: Western with a center in Lviv; Northern with a center in Kyiv; Eastern with a center in Kharkiv; Southern with a center in the Autonomous Republic of Crimea, from the year 2014, city of Odessa (Fig. 1).

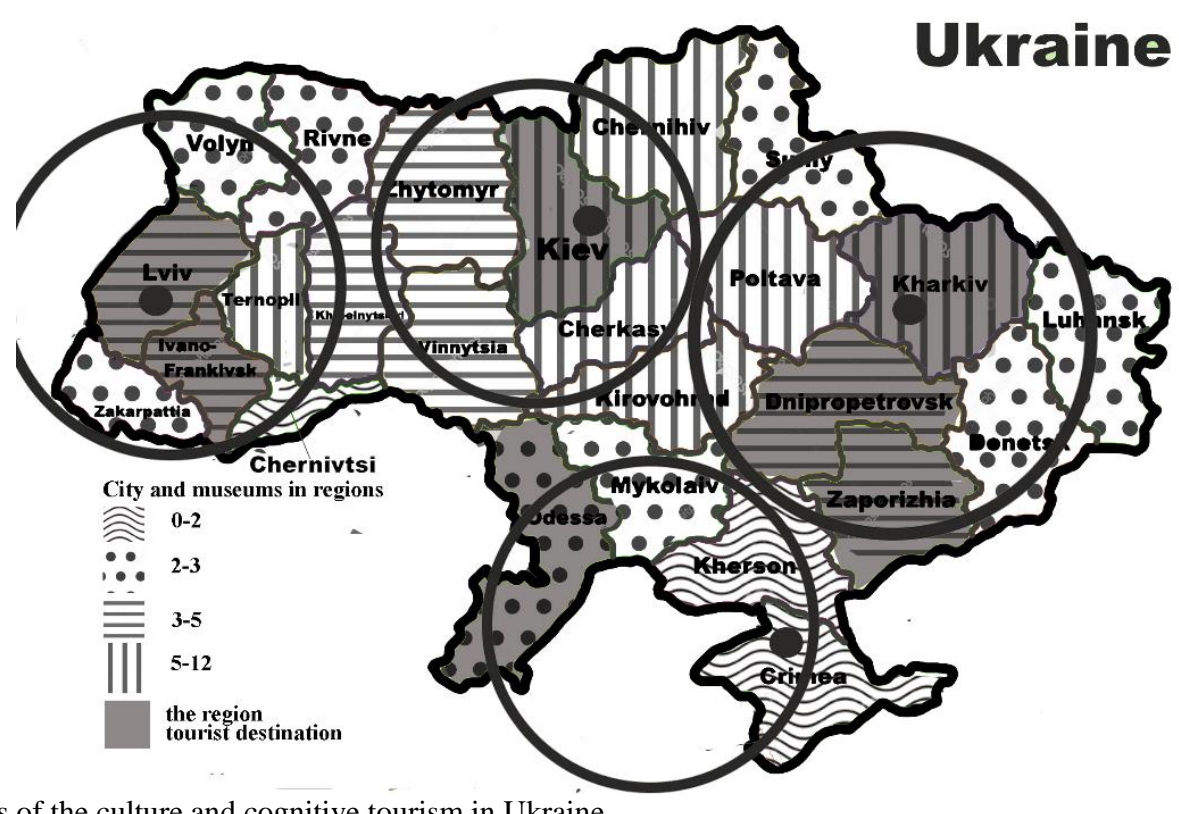

Fig. 1. The regions of the culture and cognitive tourism in Ukraine

All the other territory of Ukraine is dividedbetween them according to the theory of "concentric circles". The levelof regions attendance by the tourists, the number of museums depended largely namely on the remoteness from the existing center, except of the existence of historical monuments of all-Ukrainian or world significance, parks, etc.Taking into account the obtained results it should be included in the Western region of the cultural and cognitive tourism: Lviv; IvanoFrankivsk; Ternopil; Chernivtsi Zakarpattia; Volyn, Rivne and Khmelnytsk regions. To the North region belonged: city of Kyiv and Kyiv; Zhytomyr; Cherkasy; Chernihiv; Vinnytsia; Kirovograd regions. The Eastern region consist of: Kharkiv; Sumy; Poltava; Dnipropetrovsk; Zaporizhzhia; Donetsk; Lugansk regions. The Southern region of the cultural and cognitive tourism is formed from: the Autonomous Republic of Crimea; Kherson; Mykolaiv; Odessa regions.

In spite of the regional belonging, the development rates, the problems and priorities in all museums of Ukraine were the same. The reduction of the tourist flows, the annexation of the Crimea and the beginning of a military conflict in the eastern part of Ukraine, the lack of funding of museums, non-competitiveness of infrastructure,retardation ofthe exposition and exhibition activities of Ukrainian museums from the world's level - were the main reasons for reduction of the cultural and cognitive tourismactivity. According to the data of the State Statistics Service of Ukraine, beginning from the year 2010, the quantity of the domestic tourists in Ukraine reduced from 649 thousand to 476 thousand in 2017. Only in 2012 was an insignificant growth of the number of visitors to 773 thousand persons. Whereas, in the years 2000 and 2003 their number was respectively 1.3 million people and 1.9 million people.These circumstances also restrained the activity of foreign tourists. If in 2005 Ukraine was visited by 590 thousand people from abroad, in 2010 - 335 thousand people, then in 2015 there were only 15 thousand. Since 2016, these indicators began to increase and in 2017 reached the mark of 39 thousand people. The regressionof the domestic tourism was coming against the background ofthe rapid development of international tourism.In 2010, around 1.3 million people rested outside the borders of Ukraine, and in 2017 already 2.3 million people. According to the presented data, it can be concluded that the tourist flow in Ukraine is re-oriented in the direction of the international tourism. Ukrainians preferred to rest abroad cause of the higher quality of service and the prices adequacy, 
the better infrastructure of a recreation and leisure facilities (International tourism on track to end 2014 with record numbers, 2014).

Analyzing the development of cultural and cognitive tourism, we consider it necessary to take as the basisof research the data regarding the number of museums'visits, and not just the number of domestic tourists. In 2017, the number of domestic tourists in Ukraine, according to the State Statistics Committee, was 476 thousand people. The number of museums'visitors was 16.4 million. From which the number of pupils, students, and different listeners was 7.8 million people, the other 8.6 million visitors were private visits. In light of the difficultnessto track the private tourist trips, which, in our opinion, compose a large share of private visits of museums, we consider it expedient to rely namely on these statistical indicators.

Considering the activity of the cultural and cognitive tourism in the regions, it should be noted that the middle of the second decade of the twentyfirst century became a period of appearance of the tendencies to exit from a prolonged crisis. Its beginning is associated with the military conflict in the East of Ukraine and with the annexation of the Crimea.It cardinally reformatted the tourist flows, having changedthe market leaders. The Southern and Eastern regions, which were previously in the top of the most popular tourist destinations, became unavailable. As a result, the tourist flows are directed to the Western and Northern regions, and there is an increase in the number of trips abroad.

The biggest losses at this time weresuffered by the Southern region. The annexation of the Crimea led to the loss not only of the museums and historical monuments of the world importance, but also to the complication of movement of the tourists from the region to Ukraine. If there were 61 museums in the regionin 2010, then in 2017 their number was 35 . Similarly to this, the number of open exhibitions fell from 1153 in 2010 to 926 in 2017. The number of visitors decreased almost from 5 million people to 1.02 million people.The exposition fund, as the basis of the museum's activity and exhibitions realization, has decreased almost from 4 million units in 2010 to 1 million units in 2017. The peak of decreaseaccording to all indicators was in 2013-2014. Since 2016, there has been noted a slowincrease, but it wasn't possible to overcome the crisis and to achievethe indicators of the year 2010 (Statistical bulletin «Establishments of Culture, Arts, Physical Culture and Sports of Ukraine, 2017).

Trying to change the situation, the regional museums were making the renovations of the material and technical basis, the authority and business organizations promoted the opening of new museums (museum of chocolate, museum of science, wax-figures museum). At the same time, there was slightlychanged the methodology of museum's work, there was a small fund basis, and the expositional activity had not a large scale. All this things,restrained the attraction of new tourists, were leading to the outflow of their own.

The eastern region also suffered from the decrease of the level of the culture and cognitive tourism. Having the unique tourist and museum objects, due to the beginning of a military conflict in the East of Ukraine and the loss of control over a number of museums, it has become for the tourists as an area of risk. If in 2010 there were 161 museums in the region, then in 2014 the number was 147. Having a strong potential for the year 2017, the region succeeded to stop the fall and to achieve the pre-war level of the number of museums. There were 164 units in 2017. From the similar variations suffered the number of open exhibitions from 2536 in 2010 to 2500 in 2014. However, in 2017, there were already 3,254 . The number of visitors decreased almost from 4.8 million people to 2.8 million people in 2014. There were 3.2 million people in 2017. The expositional fund, as the basis of the museum's activity and exhibitions realization, decreased almost from 2.8 million units in 2010 to 2.3 million units in 2014. Beginning from the year of 2015, begins a slow increase, which in 2017 gave almost a pre-crisis indicatorin 2.6 million units. A feature of the region is a slow increase of the work rate, an increase ofindicators of the museum's activity and receiving of the pre-crisis indicators. This certifies about the restoration of capabilities and the transition to the phase of competitive activity (Statistical bulletin "Establishments of Culture, Arts, Physical Culture and Sports of Ukraine, 2017).

Using the existing resources, the museums of the Eastern region actively moved towardsthe updated forms of work. The increase of the number of museums and museum collections occurred with the simultaneous reorganization of the principles and methods of their work. There was a tendency for the distribution of interactive expositions, as for example, the museum of the ATO in Dniprocity.The basis for composition of the expositions of this museum became the maximum transmission of the reality of events associated with the war in the East of Ukraine: sound effects, the possibility to insight into the exposition not through the glass, but with the direct presence, etc. It is offered for the tourists a range of interesting excursions in Kharkiv like: "Good magic. Mystical excursion in Kharkiv"; "Kharkiv is a city of weird persons. A trip with a weird person"; "A backstage tour to Kharkiv Opera 
and Ballet Theater", etc. At the same time, the region develops actively an industrial, extreme tourism. Being the industrial center of Ukraine, we can see a lot ofoffersto visit mines, metallurgical plants, quarries (the deepest quarry of the world, the Southern mining and processing combine of Metinvest group of KryvyiRih city), the foundations of wine factories (Artemivsk Champagne Winery plant), and other. In combination with the historical objects (Khortytsia, Kamianamohyla, SviatohirskaLavra, and etc.), it creates a strong competitive environment, which promotes a rapid recovery of the region from the consequences of the military conflict and a slow renewal of the leading positions.

The most dynamic development was in the Northern region. Its peculiarity is that the enormous part of the indicators of museums activity was given by Kyiv. For comparison, if the number of the state museums is almost the same as in the other regions (city of Kyiv - 40, Cherkasy region - 29, Chernihiv region - 35), then the number of museum collection of the main fund is significantly more (city of Kyiv 2.2 million units; Cherkasy region - 0.6 million units, Chernihiv region - 0.5 million units), as a result, the number of visitors is significantly higher (city of Kyiv - 3.5 million visitors, Cherkasy region - 0.8 million visitors, Chernihiv region - 0.9 million visitors). Kyiv, as the administrative and political center of Ukraine, remains as the object number one in the cognitive and cultural tourism of Ukraine (Statistical bulletin «Establishments of Culture, Arts, Physical Culture and Sports of Ukraine», 2017).

Having the advantages in the administrative, historical, investment plan, during the study period, it was recorded a constant growth of the number of museums from 182 in 2010 to 210 in 2017. The number of the open exhibitions increased almost twice from 2764 in 2010 to 4367 in 2017. Also it was increased the number of items of the main fund of museums from 4 million units in 2010 to 4,3 million units in 2017. The unexpected thing in this situation is a decrease of the number of museum's visitors from 7.5 million in 2010 to 7.1 million in 2017. In spite of the dynamismof the most indicators of a development of museum sphere, the number of tourists has decreased.

Referring to the methodological and material aspects of the museums functioning, it should be noted, that the northern region is a leader for that matter. The main role in this case plays again the city of Kiev. Once you visitit you will receive a lot of offers from the classical excursions to the excursions-reconstructions where you will be served by thetourist guides dressed in ancient clothes, and the exhibit items will not be hidden behind the glass.
You can visit classical museums such as the National Museum of History of Ukraine, the Museum of Historical Treasures of Ukraine. Extreme, curiosity and interactivity impress the water museum. The museum of water will impress you with extremality, interest and interactivity. The art lovers have a possibility to visit the National Art Museum of Ukraine, Mystetskyi Arsenal, Pinchuk's Art Gallery, etc. The supporters of folklife culture and of household activities life will like the Museum of National Architecture and of Domestic Life in Pirohovo city. The presentation of a wide range of museums, their rich fund collections, makes the Northern Region and especially the city of Kyiv an unconditional leader of the cultural and cognitive tourism.

However, comparing the general coefficients of the development of four regions, it is necessary to record the appearance of a tendency of losingby Kiev of its positions. As you can see in the Table 4, the totalcoefficientof development during the years 2010-2017 was slowlyfalling, from 2.7 in 2014 to 2.07 in 2017. The reason ofit is the increasing activity of the Western region.

The western region received the most dynamic development. The historical and cultural factors, nature, crisis gave a stable rate of the cultural and cognitive tourism development. Promoted to italso the introduction of a visa-free regime with EU countries, which opened for tourists the opportunity, for relatively small sums of money, to visit for a few days different countries of the European Union. In such a way, the tourists from the Western region received the possibility to have a wider rest. It is confirmed by the data about increase of the number of museums, exhibitions, visitors, and others. If there were 142 museums in the regionin 2010, then till 2017 therewere 165 . The number of exhibitions increased from 2284 in 2010 to 3641 in 2017. The number of units for storage of the principal museum collections increased from 2.9 million in 2010 to 3.3 million in 2017. The number of museums'visitors increased from 4.5 million in 2010 to 4.8 million in 2017. At the same time, the most impressive are the development rates. As of the year 2017, they have exceeded the indicators of the Northern region. The Western region has transformed into a leader of the cultural and cognitive tourism in Ukraine. If in 2010 the total development rate was 1.3 and was at the third place from four, then in 2017, it was 2.11, havingoutranked the northern region on 0.04 .

The strong side of the Western regionalong with traditional (local history) museums became: museums-castles, historical reconstructions of battles, interactivity of the museum's work, different cultural and historical festivals. The pearl in this 
respect is Ternopil region, where is the largest number of castles in Ukraine. Attracting the tourists, they turn into the regional tourism centers, forming around them a modern tourist infrastructure. An example is Belgorod-Dniester fortress, Khotyn castle, and other. Along with it,the local museums of local history try to carry out a greatrenovation, as in the material and technical asin the methodological plan. For example, it isLviv Natural History Museum won a grant in the "Dynamic Museum" contest with the price in 10 million hryvnias. The RenatAkhmetov Foundation sponsored the reconstruction of a number of exhibit items of the Ice Age department.

As you can see, the redistribution of tourist flows, as the main indicator of the level of development of the cultural and cognitive tourism in Ukraine was from the South-East to the North-West regions. The volume of the tourist flow can be calculated with the use of coefficient of the total number of museum's visitors to the total number of the country'scitizens. In 2017, Ukrainian museums were visited by 16.5 million of people.The number of inhabitants was 42.4 million people. Having divided the number of visitors into the number of inhabitantswe can receive the indicator - 0.389. Having calculated the number of inhabitantsaccording to the conditional regions (Northern - 10.3 million people, Western - 11.3 million people, Eastern - 16.4 million people, Southern - 4.4 million people. It is excluding the temporarily occupied territories) we can get the average number of museum's visitors according to the regions (multiplying the number on the coefficient - 0,389) upon condition that the museums of these regions are visited by the inhabitants only these regions (Northern - 4 million people, Western 4.3 million people, Eastern - 6.4 million people, Southern -1.7 million people).Having compared the obtained data with the data of the State Statistics Service of Ukraine, we will find that in the Northern region, according to thecalculation of the number of the museum's visitors in the country, they should be visitedby 4 million people in 2017. However, according to the statistics data, there were there 7.1 million people ( +3.1 million). In the Western region, these figures had to compose 4.3 million of visitors, but they had 4.9 million (+0.6 million). In the Eastern region, against the expected 6.4 million of visitors, it was 3.4 million ( -3 million), while in the Southern instead of 1.7 million was only 1 million of visitors (-0.7 million).The obtained data certifiesabout the demand of the Northern and Western directions of the cultural and cognitive tourism. The data about the density of the population in the regions convince in the correctness of the statement. If we compare the population of four centers of the cultural and cognitive tourism, we will see that the highest density of population has the Eastern region - 0,39, and then goes the Western 0,27 , the Northern - 0,24 and the Southern - 0,1. As we can see, the main supplier of the cultural and cognitive tourism supporters was the Eastern Region. Relying on it,we can talk about the natural motion of masses from more densely populated areas to less densely populated, but with better tourist infrastructure and with the other museum themes. The desire toreceive new impressions, the desire to see something new became the main reason for visiting other territories. The similar tendencies were typical also for the population of the Western, Northern regions. However, a smaller number of inhabitants could not cover the number of tourist flows from a region with a larger number of population (Statistical bulletin «Establishments of Culture, Arts, Physical Culture and Sports of Ukraine», 2017).

The regional differences also were in a profit level of the cultural and cognitive tourism. Having taken as a basis thework indicators of the subjects of tourism activity -the natural persons and legal entities, it can be noted as the different activity in the regions, as the transformation of the markets. According to the results of the work for 2011, 2015, 2017, the continuous profitability showed only the Northern Region (in a greater degree due to Kyiv). Both as legal entities,assole proprietorshad an income increase from year to year, which totally composed 23 million hryvnias in 2011, 28 million hryvnias in 2015, and 38 million hryvnias in 2017. However, due to the general rate of income from the tourism activity, the part of excursions for legal entities fell from 0.007 in 2011 to 0.001 in 2017. While the coefficient for the sole proprietors has risen from 0,006 in 2011 to 0,4 in 2017, whatcan indicate about transformation of the market and growth of a role of the sole proprietors - small businesses. The big business issued step by step from this sector. The similar processes occurred in the Western region. Although the total profitableness of excursions in the region varied from 150 million hryvnias in 2011 to 10 million hryvnias in 2015 and 20 million hryvnias in 2017. Thecoefficientof profit from the excursions activity from the total profit amount from the tourist activity for the legal entities fell from 0.4 in 2011 to 0.01 in 2017 . At the same time, the coefficientamong the sole proprietorsrose from 0.1 in 2011 to almost 0.5 in 2017. As you can see, the activation of a small business gave some advantages. The possibility ofthefast work redesigning, the updating of principles, forms and 
methods of work at the demand of the market had more demand among customers.

The other tendencies were in the Southern and Eastern regions - reduction of profits from the excursions activity within the context of the total income forthe sole proprietors and increase for the legal entities. Thus, in the Eastern region, it decreased for thesole proprietors from 0.02 in 2011 to 0.01 in 2017. At the same time, it increasedfor the legal entities from0,031 in 2011 to 0.035 in 2017. In the Southern region, these indicators were $0.2 \%$ for the natural persons in 2011 and 0.02 in 2017, for legal entities $0.3 \%$ in 2011 and 0.5 for 2017.

So, Ukrainian museums have already made the first steps to update their work, to move to the modern technologies and methods. It should be considered as the doubtless achievements the introduction of interactive approaches, creative platforms, modern technologies, the phased transformation of museums into the leisure center for the whole family. A family - as an object of the tourist attention became as the main goal of the cultural and cognitive tourism. Accordingly to it, it was rebuilt the marketing system of museums' work. There were introduced the family days formuseums visiting, extended the exposition'ssubjects, opened the cafes and recreation areas in museums. Such policy encourages people to go to rest namely there, to spend there the whole day and, as a result, to eat, to have fun, to buy things. The museum in this aspect acts as a thing of attraction: a comfortable rest area, a space for the psychological influence of marketing techniques.

It became traditional for the museums the conduction of the folk festivals, invitation of musicians, culinary specialists, narrators and craftsmen of all the world, who willingly arrive to announce themselves and to show their skills. The amusement parks, creative workshops, music exhibitions and interactive educational presentations are created. An exhibition activity is often accompaniedwith master classes, offers for the visitors to try to recreate a world masterpiece. The history is presented in the form of reconstructions, historical theater, what makes it more interesting and lively, the contact with an exhibit item is permitted and encouraged in the literal sense of the word. The new types of services are simultaneously introduced: conduction of conferences, business meetings, celebration ofweddings, birthdays. The museum becomes open for people with special needs, difficult material situation (with the method of volunteer work).

Such approaches are accompanied with the use of modern information technologies for information propaganda outside of their region.
Ukrainian cultural institutions were able to join the all-European project of the virtual museum network Europeana.eu, which provides an unlimited access to the virtual libraries, archives and collections of the leading European galleries, museums and libraries. Thanks to the sponsorship, the material base of museums is improving step by step. This allows digitizing of the materials for the placement themfor a free access on the Internet. Toquicken of this type of work is directed on to the agreement of Google Corporation with the Ministry of Culture of Ukraine. In 2017, they started the project - a virtual tour throughout the museums. The idea consists of the possibility for people to view an exposition of the institution before visiting it. Within the framework of the project, seven Ukrainian museums have been alreadydigitized, namely:"Pirogovo" and "MamaievaSloboda" in Kyiv, "Shevchenkivskyihai" in Lviv, the famous national park"Khortytsia" in Zaporizhzhia and the residence of Bohdan Khmelnytskyi. Thanks to this, anyone who wishes can not only visit museums online, but also study the architectural structure from the inside, using 360degree panoramas. The virtual excursion is accompanied with a voice guide, which tells in three languages about the cultural heritage of Ukraine. Another artistic project Google - Art Project, allows a person, who has an access to the Internet, to visit the world's largest museums online. At the moment, there are materials of 17 museums from nine countries, and 385 exhibition hallsin a free access. The distribution of 3D digitization allows museums to uncover themselves completely, placing in the "virtual world" the rest of the exhibit units, which are in the storage areas and not exposed (Korolov).

An interesting innovation was the use of 3Dprinter. The spread of this technology can be a revolution in the field of museum affairs. This will promote the quickeningof collection (copying) of the most of the artifacts of the world in one place, and it will intensify the battle between museums in the field of service and marketing, and not just the objectiveness. In this case,the advantage will be determined by the technical and technological capabilities and by the creativity of the museums' employees regardingthe leisure activities organization, exhibiting interest, etc. (Kopytko).

Along with this, the main problems of the development of museums of Ukraine remain the volume of the state financing. Today, most of the budget financing is spent on the consumption charges (salaries, security, utility fees, etc.), and the development charges not only do not increase, but decrease. According to data of the directors of historical museums, $85 \%$ of the museum's budget goes to pay salaries for employees, $15 \%$ - to pay 
utility bills, while in the territory of the civilized countries to pay salaries goes only $5-10 \%$ of the total budget. Over the past years, the funding from the Ministry of Culture of Ukraine cannot provide a radical modernization of museums. In 2000, it received 0.2 milliardhryvniasfor its needs, 1.7 milliardhryvniasin 2010, 2.4 milliardhryvniasin 2015, and 4 milliardhryvniasin 2017. At the same time, the total share of expenses from the budget did not exceed $0.005 \%$. For example, the construction only of one modern building like - "Donbass Arena" costed to the customer 400 million US dollars, which at the rate of 1 US dollarid equal to 25 , and composes 10 milliards. There were spent 300 million US dollars to build an art museum in Japan. Therefore, the construction of modern museum complexes is an unmanageable thing for the Ministry of Culture of Ukraine (Statistical yearbook "Tourist activity in Ukraine", 2017).

A weak financing in turn generates a staffing problem. In museums, most of all, work people of middle and older age, and there are a small number of young people, as this work for them is not prestigious and is low-paid. However, the staffing problem lies not so much in the lack of professional museologists, as in professional museum managers. In Ukraine, specialists in museum affairs are trained by several higher educational institutions, Kharkiv State Academy of Culture, Kyiv National University of Culture and Arts, and etc. However, a significant part of graduates goes to work not according to the specialty cause of low salaries. The introduction of the museum manager position would help to search the potential donors, to work with sponsors and to build the financial system of museums of Ukraine according to the world standards. In the world, only $30-50 \%$ of the budget of museums is provided by the state, the rest is composed of charitable donations from the benevolent people or proceeds from the paid museum services. The construction of such stable financial system of a museum must be managed by a museum manager (Shlepakova, 2015).

To solve common problems and to spread the existing achievements of individual museums would largelypromote to the affirmation of the State Program for the Development of Museum Affairs and Cultural and cognitive Tourism in Ukraine. A similar program operated in 2000-2005. In 2012, the Museum Council (a special consultative and advisory body under the Ministry of Culture of Ukraine) considered and approved in April 2013 a draft Concept of the State Target-oriented NationalCultural Program for Development of the Museum Industry till 2018. However, the document remained on paper.
Conclusions. So, the level of development of the cultural and cognitive tourism depends on many factors: socio-political and economic situation in the country; a level of use of the modern technologies for museum work; the number of proposed performances, etc. That's why about $52 \%$ of Ukrainian and World tourists continue consistently to choose as the purpose for their travel -leisure. Visiting of the museums, historical monuments, parks, national parks is a binding holiday item for most tourists. The main form to carry out this item is excursions and visits of museums. For many countries of the world, museums, historical monuments, parks became as the main source of budget revenues. The countries of Europe, of the Middle East have reoriented long time ago their economies on the demands of the tourist market and actively offer the capturing tours of different plans on it. The popularity of this type of tourism is conditioned by the possibility to obtainfor some insignificant paythe maximum volume of information about the country of stay, the peculiarities of its culture and history, and to receive the positive impressions and memoriesabout the rest.

It is reasonable to emphasis four historically formed regionsof the cultural and cognitive tourism in Ukraine: Western, including Lviv, IvanoFrankivsk, Ternopil, Chernivtsi, Zakarpattia, Volyn, Rivne and Khmelnytsk regions; Northern -city of Kyiv and Kyiv, Zhytomyr, Cherkasy, Chernigiv, Vinnytsia, and Kirovograd regions; Eastern Kharkiv, Sumy, Poltava, Dnipropetrovsk, Zaporizhzhia, Donetsk, Luhansk regions; Southern the Autonomous Republic of Crimea, Kherson, Mykolaiv, Odesa regions. The beginning of the second decade of the twenty-first centuryhad the reorientation of tourist flows from the South-East regions to the North-West. The reason for this is the annexation of the Crimea and the beginning of a military conflict in the East of Ukraine. The most negatively these circumstances affected the Southern region. The loss of control over the Crimean peninsula, the weak museum resource of Mykolaiv, Kherson, Odessa regions led to the loss of their own tourists and to the inability to attract them from the other regions. Also the Eastern region suffered significant losses from the military conflict in the East of Ukraine.However, in spite of the all complicationstill the year 2017, it was able to reach the pre-crisis indicatorsby the number of museums and tourists. The region actively introduced the industrial theme of the museum exhibitions and excursiontrips. The Northern region is characterized with asteadyjob. It demonstrated the highest indicators of the cultural and cognitive tourism, which was largely due to the city of Kiev. Being the 
location of all national museums of the country, Kiev could satisfy the tastes of any direction of the cultural and cognitive tourism. However, the comparative data certifies a gradual loss of leadership in the North region. If in a quantitative sense it continued to be the most visited place, then in the coefficient sense, in 2017, according to the rate of development it gave way to the Western region. TheWestern region has demonstrated a steady growth rates over the whole period of study. The use of natural and historical advantages gave the possibility to attract the tourists from the other regions. At the same time, the fact of population density of the regions needs to be taken into account. By virtue ofit, we can talk about the natural masses motion from the most densely populated areas to the less densely populated areas. The desire to get new impressions, the desire to see something new became the main reason to visit other territories. The similar tendencies were typical alsofor the population of the Western, Northern regions. However, a smaller number of people could not cover the number of tourist flows from the region with a larger population. The tourist activity of foreigners was low. The reason is the military conflict in the East of the country and the annexation of the Crimean Peninsula, a poor modernization of the museum sphere, the low level of financing and investmentsattraction.

\section{References}

Barna, O., Serea, C., 2017. Historical monuments as tourist's attractions in Europe. Journal of tourism studies and research in tourism. 23 Retrieved from http://www.revistadeturism.ro/rdt/article/view/356

Beidyk, O.O., 2010. Rekreatsiini resursy Ukrainy [Recreational resources of Ukraine]. Alterpres, Kyiv (in Ukrainian).

Beketova, V.M., 1998. Muzei i maibutnie: tendentsii rozvytku muzeiv u sviti na mezhi tysiacholit [Museum and the future: trends in the development of museums in the world at the turn of the millennium]. Polihrafist, Dnipropetrovsk (in Ukrainian).

Gorina, G.O., 2015. Kontseptualni zasady ta perspektyvy rozvytku turystychnoi industrii Ukrainy [Conceptual framework and prospects of the Ukrainian tourism industry development]. Trade and Market of Ukraine. 38, 45-53 (in Ukrainian).

International tourism on track to end 2014 with record numbers, 2014. Retrieved from http://media.unwto.org/press-release/2014-1218/international-tourism-track-end-2014-recordnumbers

Kliuchko, Yu.M., 2011. Diialnist muzeiv u konteksti rozvytku kulturnoho turyzmu [Activities of museums in the context of cultural tourism development]. Proc. International Scientific
Conference «Conceptual problems of development of Ukrainian culture in light of the preparation and holding of 2012 as the year of culture and the revival of museums in Ukraine». Kyiv. 73-76 (in Ukrainian).

Kopytko, O. 3D Revolution: The Smithsonian Institution museum's collection can be printed on a $3 \mathrm{D}$ printer. Retrieved from http://hvylya.net/analytics/tech/3d-revolyutsiyakollektsiyu-muzeev-smithsonian-institutionmozhno-budet-raspechatat-na-3d-printere.html (in Ukrainian).

Korolov, Ye. Google digitized Ukrainian museums. Retrieved from https://techtoday.in.ua/news/google-otsifruvavukrayinskimuzeyi76711.html?gclid=CjwKCAjwl_PNBRBc EiwA4pplRaIiJlAwnnKkFLm2e3aT9MHr7iKywJVhv7yo 74ENHaeZMbyKna8fRoCPJoQAvD_BwE

Kosharnyi, V.O., 2017. Kharakterystyka turystychnykh rekreatsiinykh zon Ukrainy ta yikh udoskonalennia na osnovi derzhavno-pryvatnoho partnerstva [Characteristics of tourist recreational zones of Ukraine and their improvement on the basis of public-private partnership]. Economy and management in transport. 4, 116-123 (in Ukrainian).

Malska, M., Khudo, V., 2007. Turystychnyi biznes: teoriia ta praktyka [Travel business: theory and practice]. Center for educational literature, Kyiv (in Ukrainian).

Melko, L.F., 2013. Etnohrafichnyi turyzm yak skladova kulturno-piznavalnoho turyzmu [Ethnographic tourism as a component of cultural and cognitive tourism]. Tourism in the context of modern measurement. 1, 61-65 (in Ukrainian).

Shlepakova, T. L., 2015. On some aspects of the introduction of new management models in the Ukrainian museum industry. Retrieved from http://nplu.org/storage/files/Infocentr/Tematich ogliadi/2015/Myznew.pdf (in Ukrainian).

Smith ,M., Robinson, M, 2005.Cultural Tourism in a Changing World.The Cromwell Press, Great Britain.

Statistical yearbook «Tourist activity in Ukraine», 2017. Retrieved from http://www.ukrstat.gov.ua (in Ukrainian).

Statistical bulletin «Establishments of Culture, Arts, Physical Culture and Sports of Ukraine», 2017. Retrieved

from http://www.ukrstat.gov.ua/druk/publicat/Arhiv_u/ 15/Arch zkm bl.htm (in Ukrainian).

Vyshnevska, H.H., 2013. Potentsial kulturno-piznavalnoho turyzmu u zberezhenni kulturnoi spadshchyny Ukrainy [Potential of cultural and cognitive tourism in the preservation of cultural heritage of Ukraine]. Ukrainian culture: past, modern, ways of development. 19 (2), 192-196 (in Ukrainian).

Zbuchea, A., 2012. Cultural interests while on holidays. An exploratory investigation.Journal of Tourism Challenges and Trends. 2, 11-34. 